Martínez-Gil, A. M., del Alamo-Sanza, M., Gutiérrez-Gamboa, G., Moreno-Simunovic, Y., \& Nevares, I. (2018).

Volatile composition and sensory characteristics of Carménère wines macerating with Colombian (Quercus humboldtii) oak chips compared to wines macerated with American (Q. alba) and European (Q. petraea) oak chips.

Food Chemistry, 266, 90-100. https://doi.org/10.1016/j.foodchem.2018.05.123

\title{
Volatile composition and sensory characteristics of Carménère wines macerating with Colombian (Quercus humboldtii) oak chips compared to wines macerated with American (Q. alba) and European (Q. petraea) oak chips
}

\section{Running title: Characteristics of Carménère wines aged with Quercus humboldtii oak chips}

Ana M. Martínez-Gil ${ }^{\mathrm{a}, \mathrm{b}, 1^{*}}$, María del Alamo-Sanza ${ }^{\mathrm{a}, 1}$, Gastón GutiérrezGamboa $^{\mathrm{b}, \mathrm{c}}$, Yerko Moreno-Simunovic ${ }^{\mathrm{b}}$, Ignacio Nevares ${ }^{\mathrm{d}, 1}$

\author{
aDepartamento de Química Analítica, Universidad de Valladolid, ETS Ingenierías \\ Agrarias, Avda de Madrid 50, 34001 Palencia, Spain *e-mail: \\ anamaria.martinez.gil@uva.es

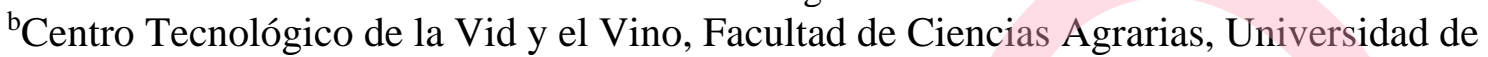 \\ Talca, Av. Lircay S/N, Talca, Chile. \\ 'Instituto de Ciencias de la Vid y del Vino (CSIC-CAR-UR). Carretera de Burgos Km. \\ 6. 26007 Logroño, Spain \\ d Departamento de Ingeniería Agroforestal, Universidad de Valladolid, ETS Ingenierías \\ Agrarias, Avda de Madrid 50, 34001 Palencia, Spain \\ ${ }^{1}$ Grupo UVaMOX, E.T.S. Ingenierías Agrarias, Universidad de Valladolid, ETS \\ Ingenierías Agrarias, Avda de Madrid 50, 34001 Palencia, Spain
}

\begin{abstract}
Different oak species or origins have been studied to find an alternative to traditional ones and Quercus humboldtii from Colombia is a candidate. Some studies analyse the composition of this oak, but no work has been found to study its use for wine treatment. The aim was to evaluate volatile composition of toasted Q. humboldtii oak chips and the wines treated with these chips. To evaluate its oenological potential Q. alba and $Q$. petraea have been included in this trial. The wines were subjected to a sensory analysis. Results indicated that oak chips and wines macerated for 90 days with toasted Colombian chips exhibited higher 5-methylfurfural, guaiacol, trans-isoeugenol and syringol concentrations than others, while the furfural and cis- $\beta$-methyl- $\gamma$-octalactone content was lower. Sensory analysis showed that the wines treated with Colombian oak presented more notes of smoked and less of coconut. Therefore, this oak could probably be considered suitable for ageing.
\end{abstract}

Keywords: Oak chips; volatile compounds; Carménère; Quercus humboldtii; traditional oaks

\section{Introduction}

The oak species usually used in cooperage are Q. alba from North America, $Q$. petraea and $Q$. robur from Europe especially in France. However, oaks from different areas in Eastern Europe (Moldova, Romania, Ukraine, Hungary and Russia) are also used for ageing wines, although their composition has hardly been studied (Díaz-Maroto, Guchu, Castro-Vázquez, de Torres \& Pérez-Coello, 2008, Prida \& Puech, 2006; Cadahía, Fernández de Simón, Vallejo, Sanz, \& Broto, 2007). The effect of using oak wood from these origins on the quality of the wine has also been widely studied (Fernández de Simón, Cadahía, \& Galocha, 2003a; Del Alamo Sanza, Nevares Domínguez, Cárcel Cárcel, \& Navas Gracia, 2004a; Del Alamo Sanza \& Nevares Domínguez, 2006; Guchu, DíazMaroto, Pérez-Coello, González-Viñas, \& Cabezudo Ibáñez, 2006; Del Alamo, Nevares, Gallego, Martin, \& Merino, 2008; Rubio-Bretón Lorenzo, Salinas, Martínez, \& GardeCerdán, 2012). Currently, traditional ageing for wines is changing towards the use of 
newer oak barrels, and the demand for this wood in oenology is increasing. Thus, it is necessary to search fornew sources of oak wood from different origins and species, to supply coopers with a potential alternative to the traditional ones. Due to this numerous studies are emerging where oak species other than the traditional ones $(Q$. robur, Q.petraea, and $Q$ alba) are used. Some of these are Q. pyrenaica Willd (Spain and Portugal) (Coninck Jordão, Ricardo-Da-Silva, \& Laureano, 2006; Fernández de Simón, Sanz, Cadahía, Poveda, \& Broto, 2006; Fernández de Simón et al., 2008; Fernández de Simón, Cadahía, Del Álamo, \& Nevares, 2010; Gallego, Del Alamo, Nevares, Fernández, Fernández De Simón, \& Cadahía, 2012), Q. faginea (Spain) (Cadahía, Muñoz, Fernández de Simón, \& García-Vallejo, 2001; Fernández de Simón, Cadahía, Conde, \& García-Vallejo, 2003b; Fernández de Simón, Cadahía, Conde, \& García-Vallejo, 2003c), Q. stellate (Missouri), Q. oocarpa (Costa Rica), Q. farnetto (Hungary) (Vivas, Glories, Bourgeois, \& Vitry, 1996).

"White oak" (Quercus humboldtii) is one of the main forest species in the Woods of Colombia (Avella \& Cárdenas, 2010) and its use was first established in 1996 by the Ministry for the Environment, Housing and Development (Ministerio de Ambiente, Vivienda y Desarrollo) (MAVDT). This white oak is a neotropical species found in the Three Mountains range, from $750 \mathrm{~m}$ to $3450 \mathrm{~m}$ above sea level, in 18 departments of the Colombian Andes (Antioquia, Bolívar, Boyacá, Caldas, Caquetá, Cauca, Chocó, Cundinamarca, Huila, Quindío, Risaralda, Nariño, Norte de Santander, Santander, Tolima, Valle del Cauca, Cesar and Córdoba) (Avella \& Cárdenas, 2010). This wood is hard, heavy and easy to work and its density is $0.9-1-0 \mathrm{~g} / \mathrm{cm} 3$. Traditionally it has been used for making posts, railroad ties, handles for tools, wooden rollers, charcoal, and firewood (Argoti et al., 2011). In addition this species is normally used in barrel-making: specifically two companies have employed this wood since the middle of the $20^{\text {th }}$ century. Cooperage products made from this "White oak" have normally been used to age some alcoholic beverages, such as rum (González \& Baleta, 2010) or brandy. Nowadays these cooperages with over 50 years' experience in making barrels for distillates are trying to introduce them to the wine industry, guaranteeing the same quality as that of oak traditionally used for ageing wines. However, to our knowledge there is no information about the performance of $Q$. humboldtii in winemaking.

Besides the study of the contact between oak and rums, we only know of two other studies on the composition of this oak when green, before and after toasting (González, Calderón \& Cabeza, 2008, Martínez-Gil, Cadahía, Fernández de Simón, GutiérrezGamboa, Nevares, \& Del Álamo-Sanza, 2017). In the first study on syringaldehyde and vanillin in untoasted and toasted oak, that toasted was found to show a similar vanillin concentration to $Q$. faginea, and a balanced syringaldehyde/vanillin relationship, a marker usually used to characterise oak wood quality (González, et al., 2008). In the second study, the phenolic composition (ellagitannins and low molecular weight phenols) of green Q. humboldtii was characterised and compared to traditional oak, with the most abundant phenolic acids, aldehydes and ellagitannins being the same as in $Q$. alba and $Q$. petraea, and with a phenolic composition closer to American ones (Martínez-Gil et al., 2017). These two studies suggested that $Q$. humboldtii oak has potentially good properties for wine ageing, offering an alternative to traditional oak.

Despite the fact that Carménère is commonly aged in contact with oak wood, no work on this subject has been found in the literature. Carménère (Vitis vinifera. L) is one of the most widely cultivated varieties in Chile since its arrival from Bordeaux, France, around 1851 before the phylloxera (Dactylosphaera vitifoliae) devastation of European grapevines which, to date, has played an important part in the Chilean wine industry. The phenolic and aromatic composition of this variety has previously been described by 
several authors (Dominguez \& Eduardo, 2010; Cañón, González, Alcalde, \& Bordeu, 2014; Izquierdo-Hernández, Peña-Neira, López-Solís, \& Obreque-Slier, 2016; HuamánCastilla, Mariotti-Celis, \& Pérez-Correa, 2017). Carménère grapes and wine stand out for their high concentrations of anthocyanins (malvidin), flavonols (quercetin and myricetin) and flavanols (catechin, epicatechin and epigallocatechin) (Huamán-Castilla et al., 2017), so this variety has a polyphenolic composition suitable for good ageing in contact with oak woods. Besides, it has been reported that methoxypyrazines are present in high concentrations in Carménère wines, which are responsible for the strong vegetative character found in wines elaborated from this variety (Belancic, \& Agosin, 2007). This undesirable characteristic could be avoided with the use of oak wood in the ageing of these wines. Oak wood greatly modifies the quality of wines, acquiring complex aromas, stabilising wine colour and improving taste, clarification and wine storage (GardeCerdán, \& Ancín-Azpilicueta, 2006), thus offering wine its so highly sought after quality and differentiation. Moreover, the use of alternative products to barrels (powder, granules, chips, shavings, blocks, segments, dominoes, cubes, staves, etc.) in contact with the wine is becoming more and more widespread, as it aims to transfer the compounds desired from oak wood to the wine in a cheap, fast and simple way. Nowadays there are numerous studies about the effect of these alternative products on the final quality of the wine, and it has even been compared to traditional ageing in barrels (Del Alamo-Sanza, Fernández-Escudero, \& De Castro-Torío, 2004b; Del Alamo-Sanza et al., 2008). However, although this practice is widely used in Carménère wines in Chile, no literature has been found to help understand what happens to this variety with the use of these alternatives.

The aim of this research was to assess the volatile composition of Quercus humboldtii toasted oak wood and the Carménère wines treated with chips of this alternative and evaluate whether these differences were expressed in a sensory analysis. To evaluate its oenological potential, oak woods normally used in cooperage; Quercus alba (American) and Quercus petraea (French and Romanian), have been included simultaneously in this trial.

\section{Materials and methods}

\subsection{Oak chips}

To carry out this study four different oak woods (origin and/or species) were used: Quercus petraea (Matt.) Liebl. (French oak from Vosges mountains and Romanian oak from Semenic mountains), Quercus alba L. (American oak from Pennsylvania mountains) and Quercus humboldtii Bonpl (Colombian oak from North of the Colombian Andes). The French, Romanian and American green oak woods were imported to Chile by the Tonelería Nacional Chile LTDA (Santiago, Chile) company. Then, the maturation process of these staves was carried out as usually done by this cooperage for these woods. The raw material was stored in special wooden castles to improve air circulation and curing by exposure to the sun, wind, occasional rain and extra addition of water for washing and drying during 30 months. After seasoning, these staves presented a moisture content (MC) between 11 and 13\%. In addition, the Colombian oak staves were imported by Tonelería Nacional Chile LTDA after the usual semi-accelerated seasoning process, as normally done in cooperage for distilled beverages. The fact that this oak has a low ellagitannin content (Martínez-Gil et al., 2017) suggests that, after drying in the usual way for beverages like brandy or rum, it may have correct properties for wine ageing too. This semi-accelerated seasoning was carried out with steam in special rooms, where the temperature gradually increases, starting at $22{ }^{\circ} \mathrm{C}$ for the first few days of drying and 
ending with $60{ }^{\circ} \mathrm{C}$. This process was finished when the oak had around 12 to $14 \%$ of MC and took approximately 3 weeks. Subsequently, the oven was turned off, and the oak was slowly adjusted to room temperature (36-48 hours).

After seasoning, all the stave oak woods (French, Romanian, American and Colombian) were toasted in an industrial-scale convection oven, where the cooperage normally carries out this process for alternative products. Toasting was classified as medium-high, which consists of a ramp of temperature up to $210{ }^{\circ} \mathrm{C}$ for 140 minutes in an industrial-scale convection oven and then processed in a woodchipper pieces of approximately $1 \mathrm{x} 0.5 \mathrm{~cm}^{2}$.

Before chipping the oak, six staves from each batch $\left(1 \mathrm{~m}^{3}\right.$ of staves) were taken for the subsequent chemical analyses. These staves were ground with a planerthicknesser and were mixed, forming the sawdust, which ranged from of 0.80 to $0.28 \mathrm{~mm}$ in size. This was determined as the representative batch sample. The study was performed in triplicate (3 batches), so a total of 12 representative samples were evaluated for the different oak woods (Q. petraea from France and Romania, Q alba, Q. humboldtii)

\subsection{Wine}

The wine used was a young red single-variety wine (cv. Carménère) produced on an industrial scale in 2016, located in the vineyard and winery of J. Bouchon (San Javier, Maule Valley, Chile). The chemical parameters of this wine were: alcohol degree $14.00 \%$ $\mathrm{v} / \mathrm{v}, \mathrm{pH} 3.45$, total acidity $5.28 \mathrm{~g} / \mathrm{l}$, volatile acidity $0.48 \mathrm{~g} / \mathrm{l}$, reducing sugars $1.95 \mathrm{~g} / \mathrm{l}$, total sulphur dioxide $57 \mathrm{mg} / \mathrm{l}$, colour intensity 10 and 40 of the total polyphenol index. These oenological parameters were evaluated before the wine was transferred into tanks and during macerating. After malolactic fermentation, chips from each oak wood were added to the twelve $50 \mathrm{l}$ stainless steel tanks, three for each oak (French, Romanian, American and Colombian). The wines were aged in a temperature-controlled chamber at $15 \pm 1{ }^{\circ} \mathrm{C}$ during the maceration period.. The dosage of the chips put into the tanks was $3 \mathrm{~g} / \mathrm{l}$, and samples were taken from each tank after 7, 18, 33, 60 and 90 days' maceration. After 90 days, the wines were taken out of the 12 tanks and separately bottled in $750 \mathrm{ml}$ bottles with screw buffers, then then stored for 3 months in a room without light and with a controlled temperature of $15^{\circ} \mathrm{C}$ for subsequent sensory analysis.

\subsection{Oenological parameter analysis.}

Physico-chemical parameters such as alcohol degree, $\mathrm{pH}$, total acidity (g/l tartaric acid) and volatile acidity (g/l acetic acid), total and free sulphur dioxide and reducing sugars were analysed according to the methodology established by OIV (2003). Wine colour intensity (CI) was calculated as the sum of optical density (OD) at 420, 520 and $620 \mathrm{~nm}$ and wine total polyphenols index (TPI) was measured as OD at $280 \mathrm{~nm}$ according to the methodology established by Bordeu and Scarpa (1998). All types of wine were macerated in triplicate and analysed in duplicate, the results being the average of three analyses $(n=6)$ for each type of treatment performed.

\subsection{Extraction of oak wood volatile compounds}

The maceration to extract the volatile compounds from sawdust was done based on the procedure described by Chatonnet et al., 1999. The sawdust samples (2 g) were soaked in $100 \mathrm{ml}$ of hydroalcoholic solution (12\% v/v ethanol, $6 \mathrm{~g} / \mathrm{l}$ tartaric acid, $\mathrm{pH}$ 3.2) for 15 days at a room temperature of $20^{\circ} \mathrm{C}$ and in darkness. The mixture (approximately $80 \mathrm{ml}$ depend on the wood) were filtered using cellulose filters grade 2 (Whatman, SigmaAldrich, Steinheim, Germany). Fifty $\mathrm{ml}$ of this were taken and $300 \mu \mathrm{l}$ of five internal standards ( $\gamma$-hexalactone, 2-octanol, 4,5-dimethylfurfuraldehyde, o-vanillone, and 3,4- 
dimethoxyphenol in a dose of $0.5 \mathrm{mg} / \mathrm{ml}$ in ethanol) (Sigma-Aldrich, Steinheim, Germany) were added. This mixture and the standards were then extracted following a previously reported methodology (López, Aznar, Cacho \& Ferreira 2002) for which prepacked cartridges (total volume $3 \mathrm{ml}$ ) filled with $200 \mathrm{mg}$ of LiChrolut EN resin (Merck, Darmstadt, Germany) were used. For this, the fifty ml of the mixture were passed through the SPE cartridges at $2 \mathrm{ml} / \mathrm{min}$. Subsequently, the sorbent was dried by letting air pass through it at approximately -0.6 Bar during $30 \mathrm{~min}$. The resulting analytes were recovered by elution with $1.3 \mathrm{ml}$ of dichloromethane.

\subsection{Extraction of wine volatile compounds}

Volatile compounds were extracted by the López et al., (2002) methodology (). To do this, $50 \mathrm{ml}$ of wine with $300 \mu \mathrm{l}$ of the combined internal standards (see previous section), were passed through the prepacked cartridges (LiChrolut EN resin) under the conditions indicated above.

\subsection{Analysis of volatile compounds by GC-MS}

The separation, identification and quantification of volatile compounds from the wine were carried out using an Agilent 7890A gas chromatograph, coupled with a 5975C mass spectrometer (Agilent Technologies Inc., Santa Clara, CA, USA). The unit was equipped with a fused silica capillary column $(60 \mathrm{~m} \times 0.25 \mathrm{~mm}$ i.d., and $0.5 \mu \mathrm{m}$ phase thickness, DB-Wax, J \& W Scientific, Agilent). The carrier was helium applied at a flow rate of $1 \mathrm{ml} / \mathrm{min}$. The temperature of the injector was $250{ }^{\circ} \mathrm{C}$ and $1 \mu \mathrm{l}$ of oak or wine extract was injected. The oven temperature was initially held at $40^{\circ} \mathrm{C}$ for $5 \mathrm{~min}$, then increased linearly at a rate of $2{ }^{\circ} \mathrm{C} / \mathrm{min}$ up to $130{ }^{\circ} \mathrm{C}$ and held at that temperature for 5 min; then it was again increased at a rate of $2^{\circ} \mathrm{C} / \mathrm{min}$ up to $180^{\circ} \mathrm{C}$ and held there for $2 \mathrm{~min}$; finally it was increased linearly at a rate of $4^{\circ} \mathrm{C} / \mathrm{min}$ up to $230^{\circ} \mathrm{C}$. The analysis in the case of oak wood was carried out with two injections: in split mode (50:1) for furfural and 5methylfurfural and in splitless mode for the rest of the volatile compounds analysed; in the case of wine all the compounds analysed were by splitless mode. Ionization was carried out by electron impact at $70 \mathrm{eV}$. The operating method was a scan mode at $\mathrm{m} / \mathrm{z}$ between 30 and 300. Identification was carried out using the NIST library. The quantification of furfural, 5-methylfurfural, 5-hydroxymethyl-furfural, guaiacol, 4vinylguaiacol, eugenol, cis-isoeugenol, syringol, vanillin, trans- $\beta$-methyl- $\gamma$-octalactone and cis- $\beta$-methyl- $\gamma$-octalactone was based on seven-point calibration curves of the respective standards (Sigma-Aldrich, Steinheim, Germany) $\left(\mathrm{R}^{2}>0.95\right)$ in a $12 \%(\mathrm{v} / \mathrm{v})$ ethanol solution with $6 \mathrm{~g} / \mathrm{l}$ of tartaric acid at $\mathrm{pH}$ 3.2; analysed under the same conditions. All types of wines were macerated in triplicate and analysed in duplicate, the results being the average of three analyses $(n=6)$.

\subsection{Sensory Analysis}

A panel of ten expert judges (two females and eight males, aged between 35 and 55) with more than ten years' experience as winemakers participated in the study. The judges were all selected on the basis of their interest and availability. In order to unify the terms used on the tasting sheet all the tasters first went through a session using the book "Le nez du vin" (France). The sensory analysis was performed in a professional room prepared in accordance with ISO 8589 (2007). All the tastings were made in transparent glasses with a constant volume, $30 \mathrm{ml}$ of each wine, in accordance with ISO 3591 (1977). Between each sample, the judges were asked to rinse their mouths out with water, eat some plain crackers for $45 \mathrm{~s}$, and finally rinse again with water for another $30 \mathrm{~s}$. 
For the sensory analysis, the wines were presented in a random order. Also, the judges were served four wines per session, divided into two sections, so each wine was analyzed in duplicate. This analysis was carried out after 90 days in contact with the different oak woods. In order to prepare a representative sample of each type of oak, two $750 \mathrm{ml}$ bottles were taken from each of the three tanks containing wine treated with the same oak and mixed to obtain 9 litres of wine from each type. The analysis consisted of 15 attributes or descriptors grouped by olfactory phase (odour intensity, fermentative, varietal, fruity, oak-oak woody, spicy, clove, smoky, vanilla, almond, coconut and over woody) and gustatory phase (astringency, persistence, and balance). Panellists rated each attribute on a scale from 1 (absence) to 7 (maximum presence). They were asked to make any negative comments on the sample which would lead to them rejecting that wine at the end of the session in order to allow us to rule out the possibility that this new species delivered an unwanted compound.

\subsection{Statistical analysis}

The oenological parameters, volatile compounds and sensory analysis were statistically analysed using variance analysis (one-way ANOVA) with the SPSS Version 21.0 statistical package for Windows (SPSS, Chicago, USA). Differences between means were compared using Duncan test at 0.05 probability level. Principal component analyses (PCA) were performed to test the different oak chips and their effect on wine. Only two principal components were extracted according to the Kaiser criterion (eigenvalue $>1$ ).

The first used the volatile concentration of the following compounds: furfural, 5MF, 5HMF, guaiacol, 4-vinylguaiacol, eugenol, cis-isoeugenol, syringol, vanillin, trans- $\beta$-Methyl- $\gamma$-octalactone ( $\mu \mathrm{g} / \mathrm{g}$ ) in oak wood from Quercus alba (American oak), $Q$. petraea (French and Romanian oaks), and Q. humboldtii (Colombian oak), the second and third used the volatile concentration $(\mu \mathrm{g} / \mathrm{l})$ in Carménère wines macerating with these oak chips for 7 or 90 days, respectively, with Statgraphics Centurion 16.2.04 (StatPoint Technologies, Inc. Warrenton, USA). The results are shown in Figures 2 A, 2 B and 2 C and in Table 2 supplementary.

\section{Results and discussion}

\subsection{Oenological parameters}

Table 1 shows oenological parameters from wines aged with different oak chips: Quercus alba (American oak), Q. petraea (French and Romanian oaks) and Q.humboldtii (Colombian oak) during 7, 18, 33, 60 and 90 days' maceration.

The different oak chips did not affect alcohol degree or $\mathrm{pH}$, since no significant differences were recorded in aged wines with different oaks chips in any of the maceration times; moreover, these two parameters remained stable throughout this period. Titratable acidity showed significant differences after 7, 60 and 90 days' maceration. The wine treated with French oak chips showed a lower value than those macerated with the other chips after 7 and 90 days, although at 90 days there was no significant difference with respect to Romanian oak, which presented the lowest value of total acidity after 60 days (Table 1). In wines, volatile acidity increased until 33 days' maceration and subsequently remained constant. Only at this point (33 days' maceration) were any significant differences found, since its content was higher in wines aged with American and Colombian oak chips.

The colour intensity of the wines is modified by the maceration time and the type of oak wood used. An increase in CI was observed during the first few days of maceration with all the types of oak studied. The wines macerated together with $Q$. petraea and $Q$. 
humboldtii oak chips showed an increase of this parameter until day 60; however, the wine from Q. alba only presented this increase until day 33. In addition, the increase was greater when Colombian oaks chips were used, increasing $27 \%$, followed by those macerated with Q. petraea showing an increase of 24 and 17\% (French and Romanian, respectively) and finally the wine in contact with American oak that only presented an increase of 1 point (10\%).The increase in the colour index during the first few days' maceration can be attributed mainly to the condensation processes between anthocyaninstannins and the co-pigmentation phenomena that can lead to the formation of new pigments in the wine, thus enhancing its colour (Revilla, \& González-Sanjosé, 2001). This component decreased in the wine with the increased maceration time: at 33 days in wines from American oak and at 60 days with the other types (Q. petraea and $Q$. humboldtii). This decrease was greater in wines macerated with French oak (37\%) and lower in wines macerated with American oak (22\%), so Colombian oak treated wines fell between these at 34\%. The decrease in CI occurring after 33 or 60 days' maceration may be explained because the anthocyanin compounds can be involved in oxidation reactions which may decrease red wine colour (Gortzi, Metaxa, Mantanis, \& Lalas, 2013). The increase in CI followed by a decrease during the oak maceration time in wines treated with chips has previously been observed by other authors (Del Alamo-Sanza et al., 2004b). The significant differences found in CI after 33 and 60 days could be attributed to the different behaviour depending on the oak wood species used. Initially, the CI of the wine in contact with French oak was higher than in the wines macerated with the other species. However, at the end of the maceration period CI content was significantly higher in the wines macerated with American oak chips than French samples, but without any significant differences.

Total polyphenol content showed a quick accumulation in the first 7 days (TPI with an initial value of 39.50) (Table 1). TPI during the maceration process remained constant or decreased with respect to the first week of maceration with oak. The results obtained show some differences as reported by Del Alamo-Sanza et al., (2004b) who stated that total phenolic compounds in wines decreased progressively during the first two months' maceration with oak chips. However, the behaviour related to increases and decreases in TPI content were also recorded by Frangipane, De Santis and Ceccarelli (2007) in wines aged with $5 \mathrm{~g} / \mathrm{l}$ oak chips. Due to the different behaviour during the diverse maceration times, significant differences were observed in this index depending on the type of oak used. However, these significant differences disappeared after 90 days' maceration for all types of oak wood.

The wines macerated in contact with Colombian oak were observed to have shown similar behaviour of the oenological parameters, both in values and in time, to the wines macerated with traditional oak woods.

\subsection{Volatile composition of toasted oak wood}

The volatile composition of oak wood from Quercus. alba (American oak), Q. petraea (French and Romanian oaks), and Q. humboldtii (Colombian oak) is shown in Table 2.

The toasted oak wood of, Q. humboldtii compared to Q. petraea and Q. alba presented significantly lower concentrations of furfural, cis- $\beta$-methyl- $\gamma$-octalactone and 5-hydroxymethyl-furfural (5HMF), although the last named showed no significant differences to French oak. On the other hand, Q. humboldtiihad a significantly higher concentration of 5-methyl-furfural (5MF), guaiacol, 4-vinylguaiacol (4VG), cisisoeugenol, and syringol than Q. petraea and Q. alba. Moreover, eugenol concentration 
from Romanian and Colombian oak woods was higher than in the traditional ones (American and French samples).

Q. alba oak showed the highest content of furfural, vanillin, acetovanillone and cis- $\beta$-methyl- $\gamma$-octalactone. Some researchers have observed that cis- $\beta$-methyl- $\gamma$ octalactone and furfural contents are higher in American oak when compared to French oak; however, in different studies the tendency is not clear, since some recorded higher compound levels in American or in French oak (Fernández de Simón et al., 2003b; Natali, Chinnici, \& Riponi,2006; Díaz-Maroto et al.,2008). Moreover, oak wood from Q. petraea presented lower concentrations of guaiacol, 4-vinylguaiacol and syringol than the rest of the species. However, the contents of 5HMF and trans- $\beta$-methyl- $\gamma$-octalactone in Romanian oak wood were the highest. The differences between the two origins of $Q$. petraea oak were observed in furfural, $5 \mathrm{HMF}$, eugenol and trans- $\beta$-methyl- $\gamma$-octalactone concentrations, since Romanian oak had significantly higher contents. Prida and Puech, (2006), in a study on the influence of geographical origin, reported differences in the content of extractives from oak wood of these origins.

\subsection{Evolution of oak volatile compounds during Carménère wine maceration with oak chips}

The extraction kinetics of oak-related volatile compounds (furfural, 5methylfurfural (5MF), 5-hydroxymethylfurfural (5HMF), guaiacol, 4-vinylguaicol (4VG), eugenol, cis-isoeugenol, syringol, vanillin, trans- $\beta$-methyl- $\gamma$-octalactone and cis$\beta$-methyl- $\gamma$-octalactone) from Carménère wines macerated with different oak chips: Quercus alba (American oak), Q. petraea (French and Romanian oak) and Q. humboldtii (Colombian oak) over the course of 90 days are shown in Figures 1a and 1b. Moreover, the statistical differences of these compounds among the different oak woods (American, French, Romanian and Colombian) at 7 and 90 days' maceration are shown in Table 3.

The only volatile compounds quantified in wine before oak wood contact (0 days) were $4 \mathrm{VG}$ and syringol. The only compound that showed a constant or slight decrease in concentration after 7 days' maceration with oak chips was 4-VG (Figure 1a). In Rodríguez-Bencomo, Ortega-Heras, Pérez-Magariño and González-Huerta's study (2009) in Tinta del País wines aged with Spanish, American and French oak chips for 60 days this compound, 4VG, was also observed in the initial wine before contact with oak and decreased when this was macerated with chips. This decrease was more significant, as a decrease of approximately 90\% was observed after 2 months while our greatest decrease of $12 \%$ was recorded after 3 months, probably because their initial concentration was higher: about $110 \mu \mathrm{g} / \mathrm{l}$. The fact that the oak contained this compound can be explained since it has been observed to form different reactions with anthocyanin compounds and is usually absorbed by the wood (Schwarz, Wabnitz, \& Winterhalter, 2003; Barrera-Garcíaet al., 2006) or transformed into 4-ethylguaiacol. The concentration of this compound after 7 days' contact with the different species or origins of oak chips was similar in all wines, since no significant differences were found between them. However, after 90 days the wine that presented the highest concentration was that in contact with Colombian chips, but without any significant differences to American and French wines (Table 3). Q. humboldtii was also the oak with the highest concentration of this compound (Table 2). However, the concentration of this compound was below its perception threshold (40 $\mu \mathrm{g} / \mathrm{l}$, phenolic and smoky notes)(Culleré, Escudero, Cacho, \& Ferreira, 2004) in all the wines.

Furanic compounds had a similar extraction kinetic in all the wines in contact with oak chips, with the concentration of furfural, 5MF and 5HMF increasing considerably after 7 days' maceration, decreasing gradually during the oak maceration period and the 
decrease was over 50\% greater after 90 days in comparison with that found after 7 days (Table 3 and Table 1 supplementary). The only compound that showed a different kinetic was $5 \mathrm{HMF}$ in the case of wine aged with Romanian oak, since it showed an increase until day 33, after which it began to decrease (Figure 1). Other authors showed an initial increase of these compounds when the wines are aged with chips followed by a fall (Rodríguez-Bencomo, Ortega-Heras, Pérez-Magariño, González-Huerta, \& GonzálezSan José, 2008; Rodríguez-Bencomo et al. 2009; Fernández de Simón et al., 2010). This might be due to the fact that these aldehydes are biologically or chemically reduced in wine to produce their corresponding alcohols (Garde-Cerdán, \& Ancín-Azpilicueta, 2006; Rodríguez-Bencomo et al., 2009; Spillman, Pollnitz, Liacopoulos, Pardon, \& Selfton, 1998). Moreover, it is possible there are (+)-catechin-aldehyde condensations, leading to the formationof brown adducts in wines (Nonier-et al., 2008). The concentration of furanic derivatives in the wines were affected by the species or origin of oak wood used (Table 3 and Table 1 supplementary). In general, the concentration in wines depended on the concentration of these compounds in the oak, especially in the case of wines after 90 days' maceration and in the case of Colombian oak. Such is the case that Colombian oak, which had the lowest furfural and 5-HMF concentrations (Table 2 ), when put in contact with wine produced that with the lowest concentration of these volatile compounds (Table 3 and Figure 1a). The oak wood with the lowest 5MF concentration was the American one and also the wine from this oak was that with a lower concentration at almost all times except for after 90 days since there were no significant differences with respect to the French wines (Table 2 and 3). In addition, Q. humboldtii with a greater 5MF concentration and the wine aged with this oak had the highest concentration after 90 days' maceration; Romanian oak also presented the highest 5HMF as did its wine after 90 days' contact. The furfural concentration in all the woods was found to be significantly different. American wood has the highest concentration followed by the Romanian and French ones, the Colombian wood showing the lowest levels. However, these differences are not maintained in the wines as those with a higher furfural content are those treated with Romanian wood without any significant differences to those treated with French wood. The lowest content is presented by the wines treated with Colombian wood while those treated with American oak came in an intermediate position between those treated with the other woods studied: the furfural concentration is not significantly different to that found in the other wines (Table 3) .

The wine concentration of guaiacol, eugenol, cis-isoeugenol and syringol increased considerably after 7 days' maceration with Colombian oak chips and then gradually increased until 90 days (Figure 1a and b). The wines macerated with the traditional oak woods also increased these compound concentrations after 7 days but less drastically, except for eugenol in the case of that macerated with Romanian chips, which showed the highest increase at this moment. After 90 days' maceration, the wine in contact with Colombian oak chips presented the highest concentration of guaiacol, cisisoeugenol and syringol (Figures $1 \mathrm{a}$ and $\mathrm{b}$, Table 3 ). This could be due to the fact that the concentration of these 3 compounds was significantly higher in Q. humboldtii than in the other oak woods (Table 2). In the wine macerated with Colombian chips, the guaiacol concentration exceeded its olfactory threshold $(9.5 \mu \mathrm{g} / \mathrm{l}$, smoke aroma descriptor) (Culleré et al., 2004). Moreover, after 90 days' maceration, the concentration of guaiacol, cis-isoeugenol and syringol in wines macerated with American, French and Romanian oak woods were statistically similar (Table 3). On the other hand, the oak from Romania and Colombia presented a statistically higher eugenol concentration (Table 2), and the wines macerated with these were also those with the higher content and were statistically similar after 90 days' maceration. At this moment during the maceration, wines with 
Romanian oak had $15.80 \mu \mathrm{g} / \mathrm{l}$, Colombian $14.38 \mu \mathrm{g} / \mathrm{l}$, American $7.64 \mu \mathrm{g} / \mathrm{l}$ and French 3.9 $\mu \mathrm{g} / \mathrm{l}$ of eugenol. Given that the threshold of perception of this compound is $6 \mu \mathrm{g} / \mathrm{l}$, the eugenol concentration might be thought not to have a direct influence on the aroma of the wines from French oak maceration, yet in the rest of the wines this compound contributed with clove and balsamic aromatic notes (Culleré et al., 2004).

Vanillin is one of the sweet notes found in wines with a perception threshold of $60 \mu \mathrm{g} / \mathrm{l}$ (Culleré, et al., 2004). This compound has great significance in wines aged with oak wood that increase their concentration above their threshold odour, depending on the species of oak used and the type of toasting. The concentration of this compound was heavily influenced by the maceration time and by origin as well as their interaction with a p-level of 0.0000 (Table 1 supplementary). In general concentrations after 90 days' maceration were greater than after 7 days' contact, except for the Colombian wood, which presented similar concentrations at both times. The pattern of evolution of vanillin differs in wines macerating with French and Romanian oak chips from the American and Colombian wines. In the latter there appears to be a slight decrease in the vanillin concentration after two months while its concentration in wines treated with French and Romanian oak chips increased considerably at this time (Figure 2). After 7 days' maceration, Table 3 shows that the levels of vanillin in Colombian wines were lower than those observed in wines aged with American and Romanian chips, the wine with a higher concentration being the one aged with French chips. After 90 days' ageing, the wine with the lowest vanillin content continued to be that aged with Colombian oak, followed by the one aged with American chips, then that aged with Romanian chips and finally the wine treated with French chips. Although Q. alba oak wood had the highest concentration of this compound, doubling the concentration in comparison with the rest of the oak woods (Table 2) as can be seen in Figure 1b, it was not the oak that gave this compound to Carménère wines. Vanillin probably has a direct influence on the wine aroma since its concentration was higher than its odour threshold: after 90 days its content was between 62 and $360 \mu \mathrm{g} / \mathrm{l}$ in Colombian wine and French wine, respectively. Therefore, this alternative oak with this type of toasting provides the wines with considerably lower amounts of vanillin than traditional oak woods, giving wines with 58\%, 76\%, 83\% less than American Romanian and French oak wood, respectively.

Regarding lactones, the isomers cis and trans of $\beta$-methyl- $\gamma$-octalactone were studied, observing how the concentration of the isomer cis was expected to be superior in all wines to the concentration of the trans isomer after contact with oak wood (RodríguezBencomo et al., 2008, 2009; Fernández de Simón et al., 2010), except for after 90 days' contact in the case of wine aged with oak from Romania, where the concentration of the trans isomer was higher than the cis isomer. Therefore, after 90 days' contact with oak wood, the smallest cis/trans ratio was presented by wine from ageing with Romanian oak (0.8), followed by French oak (1.7), then Colombian oak (2.4) and finally American oak (9.9). With respect to extraction kinetics of trans- $\beta$-methyl- $\gamma$-octalactone it can be observed that in all wines there is an extraction of this compound after 7 days' contact that remained constant until 90 days in the case of Colombian oak and until 60 days in the case of traditional oak (Figure 1b). The increase in the concentration of the isomer after 7 days in the aged Colombian oak wines was similar to that in the wines aged with French and American oak.

However, in wines aged with $Q$. humboldtii the cis and trans $\beta$-methyl- $\gamma$ octalactone content remained constant until 90 days' contact, with these wines showing the lowest concentrations of these lactones (Table 3 and Figure 1b). With respect to the wines aged with traditional oak, although they had a very similar kinetic of extraction of the trans isomer (increase after 7 and 60 days' contact), the concentration extracted by 
the wines macerated with Q. petraea of origin was much more significant in the two moments, more than triple after 7 days and more than double after 90 days. Thus, the wines treated with Romanian oak chips presented the highest concentration of trans- $\beta$ methyl- $\gamma$-octalactone at all sampling times. Probably because this wood, Romanian oak, was that with the highest concentration of this isomer (Table 2). However, in all wines the concentration of this isomer was lower than its perception threshold (790 $\mu \mathrm{g} / \mathrm{l})($ Culleré et al., 2004), so that differences in the concentration of this isomer found in wines treated with the different oaks are probably not noticeable in their final aroma. Regarding the cis$\beta$-methyl- $\gamma$-octalactone, as expected the wines macerated with American oak chips showed the highest concentration, as recorded by several authors (Rodríguez-Bencomo et al., 2008). With respect to the kinetics of this isomer, the wine aged with $Q$. humboldtii increased in the first few days of contact and remained constant over time, the same happening with wine aged with oak wood of Romanian origin; however, in the latter, the increase in concentration in wine was much more significant, as it was 6 times more than in the Colombian. However, wine from ageing with French oak wood showed a similar evolution and concentration to that aged with Colombian oak wood, until the last sampling. In 90 days the wine from ageing with oak wood of French origin increased its concentration in such a way that it was statistically equal to that wine from ageing with Romanian oak wood (Table 3, Figure 1b). The contribution from the American oak wood of this isomer to wine occurred during the entire time studied with the concentration of wine aged with $Q$. alba being 4 times higher than that found in wines aged with $Q$. petraea and 15 times higher than $Q$. humboldtii (Table 3). In this case, the concentration of cis- $\beta$ methyl- $\gamma$-octalactone was higher than its perception threshold $(67 \mu \mathrm{g} / \mathrm{l})(\mathrm{Cullere}$ et al., 2004), especially in wines aged with traditional oak, since in the case of wine aged with Colombian oak it would be at the limit (22 $\mu \mathrm{g} / \mathrm{l})$. Rodriguez Becomo et al., (2009) and Fernandez de Simón et al., (2010), observed that the evolution in wine of these two isomers depend mainly due to the principle of putting oak wood of different origins in contact with wine,.., as seen in our results. In short, the wines macerated with Colombian oak chips presented lower trans- $\beta$-methyl- $\gamma$-octalactone and cis- $\beta$-methyl- $\gamma$-octalactone, so it can be considered an oak that will barely contribute coconut aromas.

\subsection{Treatment classification}

The oak PCA (Figure 3 A, Table 2 supplementary) showed that component 1 (PC1) explained $60.2 \%$ of the variance and PC2 explained $21.0 \%$ of the variance, representing $81.2 \%$ of all variance. The compounds guaiacol, 4VG, syringol, 5HMF and cis-isoeugenol have a positive weight on the PC1 component while furfural and cis- $\beta$ methyl- $\gamma$-octalactone,are significant on the negative axis of the PC1 component. In contrast PC2 is defined on the positive axis by eugenol, trans- $\beta$-methyl- $\gamma$-octalactone and $5 \mathrm{HMF}$.Both PCs allowed differentiation between the volatile composition of species and origin. Colombian oak was defined by 5MF, guaiacol 4VG, syringol, trans-isoeugenol. Romanian oak was correlated with 5HMF, eugenol and trans- $\beta$-methyl- $\gamma$-octalactone, and American and French oak woods were correlated with furfural, vanillin and cis- $\beta$-methyl$\gamma$-octalactone.

The other principal component analysis (PCA) was performed with the aim of identifying and evaluating the volatile compounds in Carménère wines after macerating with the different species and origin of oak chips (Figures $2 \mathrm{~B}$ and $2 \mathrm{C}$ ). These figures provide a graphical representation of the oak sample projections for each group on a plane defined by two main components ( 1 and 2). After 7 days of chips macerating, the percentage of variance was $75.0 \%$ with two components (component 1 which explained $50.4 \%$ of the variance and 2 explaining 26.4\%). And after 90 days the percentage of 
variance was $82.2 \%$ with two components (component 1 which explained $63.6 \%$ of the variance and component 2 explaining 19.2\%). It shows a wide distance between wines macerated with Colombian chips with respect to the wines macerated with the other oaks, both after 7 days and 90 days. The greater the differences, the more maceration days since the main component (PC1) has greater distance at 90 days. In figure 2B (PCA after 7 days) Colombian wine was located on the four quadrant defined by guaiacol, cisisoeugenol, and syringol; and in Figure 2C (PCA after 90 days) it was located on the same site.

Looking at the PCAs of wines and oak wood, we see that this alternative oak wood is defined by some compounds, and these same compounds later place Colombian wine. According to component 1 at 7 days the French and Colombian wines were seen to be separated from the Romanian and American oness, and these were defined with furfural, eugenol, cis and trans- $\beta$-methyl- $\gamma$-octalactone. However the French oak wines are basically defined by vanillin, 5HMF, 5MF and 4VG, while guaiacol, syringol and cisisoeugenol are of significance in the Colombian oak wines (Figure 2B). After 90 days' maceration the first component is placed, in particular separating Colombian wine from the Romanian, American and French ones, with those wines at the bottom of the graph where guaiacol, cis-isoeugenol and syringol have more weight. Romanian wines were the most positively defined by furfural, trans- $\beta$-methyl- $\gamma$-octalactone, and 5-HMF. However, the French and American wines were hardly separated after 90 days, with the variables cis- $\beta$-methyl- $\gamma$-octalactone and vanillin defining those most and these same variables are the ones that most define the oak trees of these origins (Figure 2A).

\subsection{Descriptive sensory analysis}

Figure 6 shows a "spider web" diagram for the average scores of olfactory attribute intensities of wines treated with Quercus alba (American oak), Q. petraea (French and Romanian oaks), and Q. humboldtii (Colombian oak) during 90 days' maceration.

There were significant differences between the wines macerated with the different oak woods only in the olfactory attribute, olfactory intensity, clove, smoky and coconut aromas. In the case of Colombian oak, the sensory analysis results are in agreement with the chemical analysis, since this wine presented the highest smoky and lowest coconut aroma notes. However, there were also results where sensorial and chemical analyses disagreed, as the wines from ageing with Romanian and Colombian oak should have had the highest score of clove aroma and not that from ageing with American oak. In addition, American wine showed no significant differences in coconut aroma, when this should have been where tasters could have identified this aroma most significantly. These differences between sensory and chemical analysis can be due to the synergy and antagonism of different compounds, and to the fact that it is usually several compounds that generate an aroma. Moreover, olfactory intensity was higher in wines treated with Quercus alba with respect to wines macerated with Q. petraea. According to the what is stated by certain authors, wines treated with French oak are mainly preferred by judges to those treated with American oak (Díaz-Plaza, Reyero, Pardo, Alonso \& Salinas 2002; Pérez-Coello et al., 2000). Additionally, Coninck et al. (2006) showed higher score values for intensity, toasted, wood and vanillin aroma, taste intensity and global appreciation in wines aged with Q. pyrenaica and Q. petraea compared to wines without ageing. On the other hand, there were no negative comments about the wine macerating with Colombian oak; moreover, the rest of the attributes were not differentiated from those of the wines macerating with traditional oak woods. 


\section{Conclusions}

Oak wood volatile composition from Quercus humboldtii (Colombian oak wood) has particular attributes that allow it to be distinguished from Q. alba (American oak wood) and Q. petraea (French and Romanian oaks). Toasted oak wood from Quercus humboldtii (Colombian oak woods) presented higher concentrations of 5MF, guaiacol, 4vinylguiacol, trans-isoeugenol, cis-isoeugenol, and syringol than others. In contrast, Colombian oak wood showed a lower concentration of furfural, 5HMF, and cis- $\underline{\beta}-$ methyl- $\gamma$-octalactone than the others studied. In an interesting result, vanillin, eugenol, trans- $\beta$-methyl- $\gamma$-octalactone among others did not present any significant differences compared to some of the traditional oak woods. Moreover, the volatile composition of wines macerated with Colombian oak chips for three months presented a similar relation of the compounds with the volatile composition of its oak wood. The wines macerated with $Q$. humboldtii chips showed higher concentrations of 5-methylfurfural, guaiacol, isoeugenol, trans-isoeugenol and syringol and lower furfural, 5HMF, trans- $\beta$-methyl- $\gamma$ octalactone, and cis- $\beta$-methyl- $\gamma$-octalactone content. The eugenol content in the wine, after 90 days' contact, was similar to that of wine macerated with Romanian wood, showing the highest concentrations. The chemical results are in agreement with the descriptive sensory analysis that showed more oak woody and smoky attributes in wines treated with Colombian oak chips, although the tasters could not find any more notes on clove. Moreover, the oenological parameters at day 90 in wine macerated with Colombian chips are similar to those of wine treated with traditional oak woods, since they did not present any significant differences with respect to those of French, Romanian or American wines. This research has yielded useful results showing an interesting oenological potential of $Q$. humboldtii (Colombian) as an alternative species for coopering.

\section{Acknowledgements}

Work funded by Grant $\mathrm{N}^{\mathrm{0}} 11150462$ from Fondecyt, Chile and with the collaboration of Tonelería Nacional LTDA and J.Bouchon. G.G.G thanks to Conicyt, BCH/Doctorado 72170532.This work was financed by the Ministerio de Ciencia e Innovación and FEDER funds (AGL2014-54602P) and Junta de Castilla y León (VA028U16) of Spain and by the European Regional Development Fund FEDER, Interreg Spain-Portugal Programme, under the framework of the project Iberphenol. We would like to thank Ann Holliday for her services in revising the English.

\section{References}

Avella A., \& Cárdenas L.M. (2010). Conservación y uso sostenible de los bosques de roble en el corredor de conservación guantiva-la Rusia-Iguaque, departamentos de santander y Boyacá, Colombia. Colombia Forestal, 1, 5-25.

Barrera-García, V., Gougeon, R., Voilley, A., \& Chassagne, D. (2006). Sorption behavior of volatile phenols at the oak wood/wine interfaceina model wine. Journal of Agricultural and Food Chemistry, 54, 3982-3989.

Belancic, A., \& Agosin, E. (2007). Methoxypyrazines in grapes and wines of Vitis vinifera cv. Carmenere. American Journal of Enology and Viticulture, 58, 462469.Bordeu, E., \& Scarpa JA. (1998). Análisis químico del vino. Santiago, Chile: Ediciones Universidad Católica de Chile.

Cadahía, E., Muñoz, L., Fernández de Simón, B., \& García-Vallejo, M.C. (2001) Changes in low molecular weight phenolic compounds in Spanish, French, and American oak 
woods during natural seasoning and toasting. Journal of Agricultural and Food Chemistry, 49, 1790-1798.

Cadahía, E., Fernández de Simón, B., Vallejo, R., Sanz, M., \& Broto, M. (2007). Volatile Compound Evolution in Spanish Oak Wood (Quercus petraea and Quercus pyrenaica) during Natural Seasoning. American Journal of Enology and Viticulture, 58, 163-172.

Cañón, P.M., González, Á.S., Alcalde, J.A., \& Bordeu, E. (2014). Red wine phenolic composition: The effects of summer pruning and cluster thinning. Ciencia $e$ Investigacion Agraria, 41, 235-248.

Chatonnet, P., Cutzach, I., Pons, M., \& Dubordieu, D (1999). Monitoring toasting intensity of barrels by chromatographic analysis of volatile compounds from toasted oak wood. Journal of Agricultural and Food Chemistry, 47, 4310-4318.

Coninck, G., Jordão, A.M., Ricardo-Da-Silva, J.M., \& Laureano, O. (2006). Evolution of phenolic composition and sensory properties in red wine aged in contact with Portuguese and French oak wood chips. Journal International des Sciences de la Vigne et du Vin, 40, 25-34.

Culleré, L., Escudero, A., Cacho, J., \& Ferreira, V. (2004). Gas Chromatography Olfactometry and Chemical Quantitative Study of the Aroma of Six Premium Quality Spanish Aged Red Wines. Journal of Agricultural and Food Chemistry, 52, 16531660.

Díaz-Maroto, M. C., Guchu, E., Castro-Vázquez, L., de Torres, C., \& Pérez-Coello, M. S. (2008). Aroma active compounds of American, French, Hungarian and Russian oak woods studied by Gas Chromatography-Mass Spectrometry and Gas Chromatography-Olfactometry. Flavour and Fragrance Journal, 23, 93-98.

Díaz-Plaza, E. M., Reyero, J. R., Pardo, F., Alonso, G. L., \& Salinas, M. R. (2002). Influence of oak wood on the aromatic composition and quality of wines with different tannin contents. Journal of Agricultural and Food Chemistry, 50, 26222626.Domínguez, A.M. \& Eduardo, A. (2010). Gas chromatography coupled with mass spectrometry detection for the volatile profiling of Vitis Vinifera CV. Carménère wines. Journal of the Chilean Chemical Society, 55, 385-391.

Fernández de Simón, B., Cadahía, E., \& Galocha, J. (2003a). Volatile compounds in a Spanish red wine aged in barrels made of Spanish, French, and American oak wood. Journal of Agricultural and Food Chemistry, 51, 7671-7678.

Fernández de Simón, B., Cadahía, E., Conde, E., \& García-Vallejo M.C. (2003b). Compounds in Spanish oak wood during natural seasoning. First results. Journal of Agricultural and Food Chemistry, 51, 7671-7678.

Fernández de Simón, B., Cadahía, E., Conde, E., \& García-Vallejo M.C. (2003c). Phenolic compounds in Spanish red wines aged in barrels made of Spanish, French and American oak wood. European Food Research and Technology, 216, 150-156.

Fernández de Simón, B., Sanz, M., Cadahía, E., Poveda, P., \& Broto, M. (2006). Chemical characterization of oak heartwood from Spanish forests of Quercus pyrenaica (Wild.). Ellagitannins, low molecular weight phenolic, and volatile compounds. Journal of Agricultural and Food Chemistry, 54, 8314-832.

Fernández de Simón, B., Cadahía, E., Sanz, Del Álamo, M., Poveda, P., Perez-Magariño, S., Ortega-Heras, M., \& González-Huerta, C. (2008). Volatile compounds and sensorial characterization of wines from four Spanish denominations of origin, aged in Spanish Rebollo (Quercus pyrenaica Willd.) oak wood barrels. Journal of Agricultural and Food Chemistry, 56, 9046-9055. 
Fernández de Simón, B, Cadahía, E, Del Álamo, M, \& Nevares, I. (2010). Effect of size, seasoning and toasting in the volatile compounds in toasted oak wood and in a red wine treated with them. Analytica Chimca Acta, 660, 211-220.

Frangipane, M. T., De Santis, D., \& Ceccarelli, A. (2007) Influence of oak woods of different geographical origins on quality of wines aged in barriques and using oak chips. Food Chemistry, 103, 46-54.

Gallego, L., Del Alamo, M., Nevares, I., Fernández, J.A., Fernández De Simón, B., \& Cadahía, E. (2012). Phenolic compounds and sensorial characterization of wines aged with alternative to barrel products made of Spanish oak wood (Quercus pyrenaica Willd.). Food Science and Technology International, 18, 151-165.

Garde-Cerdán, T., \& Ancín-Azpilicueta, C. (2006). Review of quality factors on wine ageing in oak barrels. Trends in Food Science \& Technology, 17, 438-447.

González, R. E., Calderón, L. S., \& Cabeza, R. A. (2008). Quantification of aging markers substances in Quercus humboldtii through high efficiency liquid chromatography. Temas Agrarios, 13, 56-63.

González, R. E., \& Baleta, L. C. (2010) Quantification and comparison of ageing markers substances of accelerated aging rums and in oak (Quercus humboldtii) barrels. Revista Venezolana de Ciencia y Tecnologia de Alimentos, 1, 170-183.

Gortzi, O., Metaxa, X., Mantanis, G., \& Lalas, S. (2013). Effect of artificial ageing using different wood chips on the antioxidant activity, resveratrol and catechin concentration, sensory properties and colour of two Greek red wines. Food Chemistry, 141, 2887-2895.

Guchu, E., Díaz-Maroto, M.C., Pérez-Coello M.S., González-Viñas M.A. \& Cabezudo Ibáñez M.D. (2006). Volatile composition and sensory characteristics of Chardonnay wines treated with American and Hungarian oak chips. Food Chemistry, 2, 350-359.

Huamán-Castilla, N.L., Mariotti-Celis, M.S., \& Pérez-Correal, J.R., (2017). Polyphenols of Carménère Grapes. Mini-Reviews in Organic Chemistry, 14, 176-186.

ISO 3591 (1977). Sensory analysis. Apparatus wine tasting glass.

ISO 8589 (2007). Sensory analysis. General guidance for the design of test rooms

Izquierdo-Hernández, A., Peña-Neira, Á., López-Solís, R., \& Obreque-Slier, E. (2016). Comparative Determination of Anthocyanins, Low Molecular Weight Phenols, and Flavanol Fractions in Vitis vinifera L. cv Carménère Skins and Seeds by Differential Solvent Extraction and High-Performance Liquid Chromatography. Analytical Letters, 49, 1127-1142.

Koussissi, E., Dourtoglou, V. G., Ageloussis, G., Paraskevopoulos, Y., Dourtoglou, T., Paterson, A., \& Chatzilazarou, A. (2009). Influence of toasting of oak chips on red wine maturation from sensory and gas chromatographic headspace analysis. Food Chemistry, 114, 1503-1509.

López, R., Aznar, M, Cacho, J., \& Ferreira, V. (2002). Determination of minor and trace volatile compounds in wine by solid-phase extraction and gas chromatography with mass spectrometric detection. Journal of Chromatography A, 966, 167-177.

Martínez-Gil, A.M., Cadahía, E., Fernández de Simón, B., Gutiérrez-Gamboa, G., Nevares, I., \& del Álamo-Sanza, M. (2017). Quercus humboldtii (colombian oak): characterisation of wood phenolic composition with respect to traditional oak wood used in oenology. Ciência e Técnica Vitivinícola, 32, 93-101.

Natali, N., Chinnici, F., \& Riponi C. (2006). Characterization of volatiles in extracts from oak chips obtained by Accelerated Solvent Extraction (ASE). Journal of Agricultural and Food Chemistry, 54, 8190-8198. 
Martínez-Gil, A. M., del Alamo-Sanza, M., Gutiérrez-Gamboa, G., Moreno-Simunovic, Y., \& Nevares, I. (2018). Volatile composition and sensory characteristics of Carménère wines macerating with Colombian (Quercus humboldtii) oak chips compared to wines macerated with American (Q. alba) and European (Q. petraea) oak chips.

Food Chemistry, 266, 90-100. https://doi.org/10.1016/j.foodchem.2018.05.123

Nonier-Bourden, M.F., Vivas, N., Absalon, C., Vitry, C., Fouquet E., \& Vivas de Gaulejac, N. (2008). Structural diversity of nucleophilic adducts from flavanols and oak wood aldehydes. Food Chemistry, 107,1494-1505.

OIV. (2003). Compendium of internationals methods of wine and must analysis. Paris: OIV.

Pérez-Coello, M. S., Sánchez, M. A., García, E., González Viñas, M. A., Sanz, J., \& Cabezudo, M. D. (2000). Fermentation of white wines in presence of wood chips of American and French oak. Journal of Agricultural and Food Chemistry, 48, 885889.Prida, A., \& Puech, J. L. (2006). Influence of geographical origin and botanical species on the content of extractives in American, French, and East European oak woods. Journal of Agricultural and Food Chemistry, 54, 8115-8126.

Revilla, I., \& González-Sanjosé, M. L. (2001). Effect of different oak woods on aged wine color and anthocyanin composition. European Food Research and Technology, 213, 281-285.

Rodríguez-Bencomo, J., Ortega-Heras, M., Pérez-Magariño, S., González-Huerta, C., \& González-San José, M.L. (2008). Importance of Chip Selection and Elaboration Process on the Aromatic Composition of Finished Wines. Journal of Agricultural and Food Chemistry, 56, 5102-5111.

Rodríguez-Bencomo, J. J., Ortega-Heras, M., Pérez-Magariño, S., \& González-Huerta, C. (2009). Volatile compounds of red wines macerated with Spanish, American and French oak chips. Journal of Agricultural and Food Chemistry, 57, 6383-6391.

Rubio-Bretón, P., Lorenzo, C., Salinas, M.R., Martínez, J., \& Garde-Cerdán, T. (2012). Influence of oak barrel aging on the quality of red wines. In C. Aleixo Chuteira \& A. Bispo Grão (Eds.), Oak, ecology, types and management (pp. 59-86). New York: Nova Science Publishers, Inc.

Schwarz, M., Wabnitz, T.C., \& Winterhalter, P. (2003). Pathway leading to the formation of anthocyanin-vinylphenol adducts and related pigments in red wines. Journal of Agricultural and Food Chemistry, 51, 3682-3687.

Spillman, P. J., Pollnitz, A. P., Liacopoulos, D., Pardon, K. H., \& Sefton, M. A. (1998). Formation and degradation of furfuryl alcohol, 5-methylfurfuryl alcohol, vanillyl alcohol, and their ethyl ethers in barrel-aged wines. Journal of Agricultural and Food Chemistry, 46, 657-663.

Vivas, N., Glories, Y., Bourgeois, G. \& Vitry, C. (1996). The heartwood ellagitannins of different oak (Quercus sp.) and chestnut species (Castanea sativa Mill.). Quantity analysis of red wines aging in barrels. Journal of the Science of Technology Tonnellerie, 2, 51-75. 
Table 1. Oenological parameters from wines in contact with oak chips: Quercus alba: American, Q. petraea: French and Romanian, and Q. humboldtii: Colombian.

\begin{tabular}{|c|c|c|c|c|}
\hline \multirow{3}{*}{ Parameters } & \multirow{2}{*}{$\begin{array}{c}\text { Q. alba } \\
\text { American oak } \\
\end{array}$} & \multicolumn{2}{|c|}{ Q. petraea } & \multirow{2}{*}{$\begin{array}{l}\text { Q. humboldtii } \\
\text { Colombian oak }\end{array}$} \\
\hline & & French oak & Romanian oak & \\
\hline & & 7 days & & - \\
\hline Alcohol degree (\% v/v) & $14.10 \pm 0.00 \mathrm{a}$ & $14.10 \pm 0.00 \mathrm{a}$ & $14.10 \pm 0.00 \mathrm{a}$ & $14.10 \pm 0.00 \mathrm{a}$ \\
\hline $\mathrm{pH}$ & $3.36 \pm 0.01 \mathrm{a}$ & $3.37 \pm 0.01 \mathrm{a}$ & $3.37 \pm 0.01 \mathrm{a}$ & $3.38 \pm 0.01$ a. \\
\hline Total acidity $(\mathrm{g} / \mathrm{l}) *$ & $5.62 \pm 0.01 \mathrm{~b}$ & $5.45 \pm 0.04 \mathrm{a}$ & $5.60 \pm 0.04 \mathrm{~b}$ & $5.63 \pm 0.09 \mathrm{~b}$ \\
\hline Volatile acidity (g/l) & $0.48 \pm 0.00 \mathrm{a}$ & $0.49 \pm 0.01 \mathrm{a}$ & $0.48 \pm 0.00 \mathrm{a}$ & $0.48 \pm 0.00 \mathrm{a}$ \\
\hline Colour intensity & $10.42 \pm 0.05 \mathrm{a}$ & $10.79 \pm 0.14 b$ & $10.49 \pm 0.20 \mathrm{a}$ & $10.27 \pm 0.07 \mathrm{a}$ \\
\hline \multirow[t]{2}{*}{ TPI** } & $43.70 \pm 0.10 \mathrm{ab}$ & $44.23 \pm 0.61 \mathrm{~b}$ & $46.43 \pm 0.38 \mathrm{c}$ & $43.23 \pm 0.15 \mathrm{a}$ \\
\hline & & 18 days & & \\
\hline Alcohol degree (\% v/v) & $14.10 \pm 0.00 \mathrm{a}$ & $14.10 \pm 0.00 \mathrm{a}$ & $14.10 \pm 0.00 \mathrm{a}$ & $14.10 \pm 0.00 \mathrm{a}$ \\
\hline $\mathrm{pH}$ & $3.42 \pm 0.01 \mathrm{a}$ & $3.44 \pm 0.01 \mathrm{a}$ & $3.44 \pm 0.01 \mathrm{a}$ & $3.43 \pm 0.01 \mathrm{a}$ \\
\hline Total acidity (g/l)* & $5.61 \pm 0.04 \mathrm{a}$ & $5.52 \pm 0.10 \mathrm{a}$ & $5.57 \pm 0.05 \mathrm{a}$ & $5.63 \pm 0.10 \mathrm{a}$ \\
\hline Volatile acidity (g/l) & $0.51 \pm 0.01 \mathrm{a}$ & $0.49 \pm 0.01 \mathrm{a}$ & $0.50 \pm 0.02 \mathrm{a}$ & $0.50 \pm 0.01 \mathrm{a}$ \\
\hline Colour intensity & $10.93 \pm 0.67 \mathrm{a}$ & $10.41 \pm 0.41 \mathrm{a}$ & $10.93 \pm 0.52 \mathrm{a}$ & $10.75 \pm 0.32 \mathrm{a}$ \\
\hline \multirow[t]{2}{*}{ TPI** } & $42.73 \pm 1.00 \mathrm{a}$ & $44.73 \pm 0.86 b$ & $45.03 \pm 0.99 b$ & $43.10 \pm 1.14 \mathrm{ab}$ \\
\hline & & 33 days & +2 & \\
\hline Alcohol degree (\% v/v) & $14.10 \pm 0.00 \mathrm{a}$ & $14.10 \pm 0.00 \mathrm{a}$ & $14.10 \pm 0.00 \mathrm{a}$ & $14.10 \pm 0.00 \mathrm{a}$ \\
\hline $\mathrm{pH}$ & $3.39 \pm 0.00 \mathrm{a}$ & $3.39 \pm 0.01 \mathrm{a}$ & $3.39 \pm 0.02 \mathrm{a}$ & $3.38 \pm 0.01 \mathrm{a}$ \\
\hline Total acidity $\left(\mathrm{g} / \mathrm{l}^{*}\right.$ & $5.99 \pm 0.09 \mathrm{a}$ & $5.87 \pm 0.04 \mathrm{a}$ & $5.91 \pm 0.06 \mathrm{a}$ & $5.98 \pm 0.10 \mathrm{a}$ \\
\hline Volatile acidity $(\mathrm{g} / \mathrm{l})$ & $0.66 \pm 0.02 \mathrm{~b}$ & $0.59 \pm 0.01 \mathrm{a}$ & $0.61 \pm 0.02 \mathrm{a}$ & $0.67 \pm 0.02 \mathrm{~b}$ \\
\hline Colour intensity & $11.41 \pm 0.29 \mathrm{~b}$ & $10.73 \pm 0.23 \mathrm{a}$ & $11.37 \pm 0.35 b$ & $11.52 \pm 0.14 \mathrm{~b}$ \\
\hline \multirow[t]{2}{*}{ TPI** } & $40.87 \pm 0.49 \mathrm{ab}$ & $41.43 \pm 0.21 \mathrm{ab}$ & $42.30 \pm 1.13 \mathrm{~b}$ & $40.03 \pm 0.97 \mathrm{a}$ \\
\hline & & 60 days & & \\
\hline Alcohol degree (\% v/v) & $14.10 \pm 0.00 \mathrm{a}$ & $14.10 \pm 0.00 \mathrm{a}$ & $14.07 \pm 0.15 \mathrm{a}$ & $14.17 \pm 0.06 \mathrm{a}$ \\
\hline $\mathrm{pH}$ & $3.37 \pm 0.01 \mathrm{a}$ & $3.37 \pm 0.01 \mathrm{a}$ & $3.37 \pm 0.00 \mathrm{a}$ & $3.37 \pm 0.01 \mathrm{a}$ \\
\hline Total acidity (g/l)* & $5.55 \pm 0.01 \mathrm{ab}$ & $5.54 \pm 0.02 \mathrm{ab}$ & $5.46 \pm 0.08 \mathrm{a}$ & $5.57 \pm 0.05 b$ \\
\hline Volatile acidity (g/l) & $0.64 \pm 0.06 \mathrm{a}$ & $0.59 \pm 0.04 \mathrm{a}$ & $0.60 \pm 0.06 \mathrm{a}$ & $0.66 \pm 0.03 \mathrm{a}$ \\
\hline Colour intensity & $9.36 \pm 0.25 \mathrm{a}$ & $13.36 \pm 0.97 \mathrm{~b}$ & $12.30 \pm 2.55 b$ & $13.08 \pm 0.32 b$ \\
\hline \multirow[t]{2}{*}{ TPI** } & $38.77 \pm 0.75 \mathrm{a}$ & $40.70 \pm 0.53 \mathrm{~b}$ & $39.27 \pm 0.59 \mathrm{a}$ & $39.67 \pm 0.84 \mathrm{ab}$ \\
\hline & & 90 days & & \\
\hline Alcohol degree (\% v/v) & $14.07 \pm 0.06 \mathrm{a}$ & $14.10 \pm 0.00 \mathrm{a}$ & $14.13 \pm 0.06 \mathrm{a}$ & $14.13 \pm 0.06 \mathrm{a}$ \\
\hline $\mathrm{pH}$ & $3.37 \pm 0.02 \mathrm{a}$ & $3.36 \pm 0.01 \mathrm{a}$ & $3.37 \pm 0.02 \mathrm{a}$ & $3.37 \pm 0.01 \mathrm{a}$ \\
\hline Total acidity $(\mathrm{g} / \mathrm{l}) *$ & $5.66 \pm 0.10 \mathrm{~b}$ & $5.50 \pm 0.05 \mathrm{a}$ & $5.60 \pm 0.08 \mathrm{ab}$ & $5.69 \pm 0.04 b$ \\
\hline Volatile acidity (g/l) & $0.65 \pm 0.04 \mathrm{a}$ & $0.57 \pm 0.02 \mathrm{a}$ & $0.66 \pm 0.11 \mathrm{a}$ & $0.65 \pm 0.03 \mathrm{a}$ \\
\hline Colour intensity & $8.86 \pm 0.26 b$ & $8.38 \pm 0.16 \mathrm{a}$ & $8.53 \pm 0.17 \mathrm{ab}$ & $8.58 \pm 0.11 \mathrm{ab}$ \\
\hline TPI** & $43.47 \pm 5.24 \mathrm{a}$ & $41.43 \pm 1.00 \mathrm{a}$ & $42.00 \pm 5.20 \mathrm{a}$ & $44.63 \pm 6.38 \mathrm{a}$ \\
\hline
\end{tabular}

All parameters are given with their standard deviation $(n=6)$. For each parameter, different letters in the same row indicate significant differences between different oak woods $(\mathrm{p} \leq 0.05)$. * As $\mathrm{g} / \mathrm{l}$ of tartaric acid. ** Total polyphenol index. 
Martínez-Gil, A. M., del Alamo-Sanza, M., Gutiérrez-Gamboa, G., Moreno-Simunovic, Y., \& Nevares, I. (2018). Volatile composition and sensory characteristics of Carménère wines macerating with Colombian (Quercus humboldtii) oak chips compared to wines macerated with American (Q. alba) and European (Q. petraea) oak chips.

Food Chemistry, 266, 90-100. https://doi.org/10.1016/j.foodchem.2018.05.123

Table 2. Volatile composition ( $\mu \mathrm{g} / \mathrm{g}$ of wood) of toasted oak chips from Quercus alba: American,

Q. petraea: French and Romanian, and $Q$.

humboldtii: Colombian, used to macerate wines

\begin{tabular}{ccccc}
\hline \multirow{2}{*}{ Volatile Compounds } & Q. alba & \multicolumn{2}{c}{ Q. petraea } & Q. humboldtii \\
\cline { 2 - 5 } & American oak & French oak & Romanian oak & $\begin{array}{c}\text { Colombian } \\
\text { oak }\end{array}$ \\
\hline Furfural & $1363.16 \pm 41.56$ & $924.15 \pm$ & $1149.63 \pm 162.83$ & $533.53 \pm 26.20$ \\
5-Methyl-furfural (5MF) & $16.92 \pm 2.00 \mathrm{a}$ & $27.74 \pm 4.55 \mathrm{~b}$ & $23.41 \pm 5.05 \mathrm{ab}$ & $45.40 \pm 1.32 \mathrm{c}$ \\
5-Hydroxymethyl-furfural & $804.27 \pm 59.41$ & $579.01 \pm 76.76$ & $1191.90 \pm$ & $463.42 \pm 38.03$ \\
(5HMF) & $\mathrm{b}$ & $\mathrm{ab}$ & $285.05 \mathrm{c}$ & $\mathrm{a}$ \\
Guaiacol & $0.93 \pm 0.20 \mathrm{~b}$ & $0.40 \pm 0.03 \mathrm{a}$ & $0.55 \pm 0.12 \mathrm{a}$ & $3.74 \pm 0.26 \mathrm{c}$ \\
4-Vinylguaiacol (4VG) & $0.54 \pm 0.04 \mathrm{~b}$ & $0.49 \pm 0.01 \mathrm{a}$ & $0.51 \pm 0.02 \mathrm{ab}$ & $0.67 \pm 0.03 \mathrm{c}$ \\
Eugenol & $2.07 \pm 0.26 \mathrm{a}$ & $1.60 \pm 0.21 \mathrm{a}$ & $5.59 \pm 0.50 \mathrm{~b}$ & $3.34 \pm 0.19 \mathrm{~b}$ \\
cis-Isoeugenol & $1.52 \pm 0.44 \mathrm{a}$ & $1.74 \pm 0.11 \mathrm{a}$ & $2.11 \pm 0.62 \mathrm{a}$ & $7.23 \pm 0.49 \mathrm{~b}$ \\
Syringol & $3.39 \pm 0.66 \mathrm{~b}$ & $1.43 \pm 0.08 \mathrm{a}$ & $1.92 \pm 0.52 \mathrm{a}$ & $10.14 \pm 0.87 \mathrm{c}$ \\
Vanillin & $57.00 \pm 12.79 \mathrm{~b}$ & $22.54 \pm 3.89 \mathrm{a}$ & $23.18 \pm 0.80 \mathrm{a}$ & $22.36 \pm 1.21 \mathrm{a}$ \\
trans- $\beta$-Methyl- $\gamma$-octalactone & $3.47 \pm 0.42 \mathrm{a}$ & $2.05 \pm 0.21 \mathrm{a}$ & $19.51 \pm 9.75 \mathrm{~b}$ & $0.06 \pm 0.01 \mathrm{a}$ \\
cis- $\beta$-Methyl- $\gamma$-octalactone & $27.10 \pm 3.84 \mathrm{c}$ & $12.65 \pm 1.41 \mathrm{~b}$ & $13.27 \pm 7.28 \mathrm{~b}$ & $0.30 \pm 0.09 \mathrm{a}$ \\
\hline
\end{tabular}

All parameters are given with their standard deviation $(n=6)$. For each parameter, different letters in the same row indicate significant differences between different oak woods $(\mathrm{p} \leq 0.05)$. 
Table 3. Volatile composition ( $\mu \mathrm{g} / \mathrm{l})$ from wines macerating during 7 and 90 days with oak chips: Quercus alba: American, Q. petraea: French and Romanian, and Q. humboldtii: Colombian

\begin{tabular}{|c|c|c|c|c|c|c|c|c|}
\hline & \multirow{2}{*}{$\begin{array}{c}\text { Q. alba } \\
\text { American }\end{array}$} & \multicolumn{2}{|c|}{ Q. petraea } & \multirow{2}{*}{$\frac{\text { Q. humboldtii }}{\text { Colombian }}$} & \multirow{2}{*}{$\begin{array}{c}\text { Q. alba } \\
\text { American }\end{array}$} & \multicolumn{2}{|c|}{ Q. petraea } & \multirow{2}{*}{$\begin{array}{c}\text { Q. humboldtii } \\
\text { Colombian }\end{array}$} \\
\hline & & French & Romanian & & & French & Romanian & \\
\hline & \multicolumn{4}{|c|}{7 days } & \multicolumn{4}{|c|}{90 days } \\
\hline Furfural & $2940.91 \pm 64.09 \mathrm{ab}$ & $3398.22 \pm 1083.43 b$ & $3882.17 \pm 376.62 \mathrm{~b}$ & $1871.58 \pm 159.16$ a & $1421.67 \pm 55.25 b$ & $1484.77 \pm 272.75$ bc & $2192.31 \pm 704.33$ c & $511.08 \pm 17.31 \mathrm{a}$ \\
\hline 5-Methyl-furfural (5MF) & $501.35 \pm 16.60 \mathrm{a}$ & $892.59 \pm 12.45 \mathrm{c}$ & $632.08 \pm 112.15 b$ & $538.91 \pm 37.25 \mathrm{ab}$ & $180.83 \pm 36.81 \mathrm{a}$ & $189.83 \pm 28.01 \mathrm{a}$ & $260.40 \pm 38.97 \mathrm{~b}$ & $386.37 \pm 11.86 \mathrm{c}$ \\
\hline 5-Hydroxymethy-lfurfural (5HMF) & $1384.79 \pm 110.83 b$ & $2440 \pm 91.29 \mathrm{c}$ & $1443.74 \pm 394.24 b$ & $887.95 \pm 17.85$ a & $701.70 \pm 96.63 b$ & $692.86 \pm 176.37 \mathrm{~b}$ & $957.69 \pm 54.66 \mathrm{c}$ & $318.56 \pm 65.33 \mathrm{a}$ \\
\hline Guaiacol & $3.70 \pm 0.89$ a & $2.94 \pm 0.62 \mathrm{a}$ & $3.01 \pm 0.22 \mathrm{a}$ & $15.19 \pm 1.70 b$ & $3.86 \pm 0.50 \mathrm{a}$ & $3.84 \pm 0.06$ a & $3.32 \pm 0.10 \mathrm{a}$ & $25.46 \pm 7.53 b$ \\
\hline 4-Vinylguaiacol (4VG) & $12.44 \pm 0.06 \mathrm{a}$ & $12.62 \pm 0.04 \mathrm{a}$ & $12.36 \pm 0.20 \mathrm{a}$ & $12.32 \pm 2.27 \mathrm{a}$ & $12.65 \pm 0.12 \mathrm{ab}$ & $12.89 \pm 0.18 \mathrm{ab}$ & $11.87 \pm 0.57 \mathrm{a}$ & $13.57 \pm 0.91 \mathrm{~b}$ \\
\hline Eugenol & $8.03 \pm 1.69 \mathrm{ab}$ & $5.57 \pm 0.40 \mathrm{a}$ & $17.44 \pm 3.71 \mathrm{c}$ & $10.74 \pm 0.86 \mathrm{~b}$ & $7.64 \pm 0.73 \mathrm{a}$ & $3.92 \pm 0.31 \mathrm{a}$ & $15.81 \pm 4.87 \mathrm{~b}$ & $14.38 \pm 3.11 \mathrm{~b}$ \\
\hline cis-Isoeugenol & $20.10 \pm 4.37 \mathrm{~b}$ & $13.57 \pm 2.79$ a & $13.79 \pm 1.96 \mathrm{a}$ & $32.14 \pm 2.68 \mathrm{c}$ & $6.87 \pm 0.09$ a & $6.05 \pm 0.17 \mathrm{a}$ & $6.01 \pm 0.06 \mathrm{a}$ & $34.32 \pm 7.31 \mathrm{~b}$ \\
\hline Syringol & $14.11 \pm 1.63$ a & $12.72 \pm 1.73 \mathrm{a}$ & $11.83 \pm 0.92 \mathrm{a}$ & $41.68 \pm 4.40 \mathrm{~b}$ & $8.70 \pm 0.31 \mathrm{a}$ & $10.15 \pm 3.62$ a & $10.07 \pm 3.96 \mathrm{a}$ & $58.04 \pm 7.52 b$ \\
\hline Vanillin & $76.27 \pm 3.92 b$ & $104.63 \pm 4.25 \mathrm{c}$ & $80.03 \pm 4.40 \mathrm{~b}$ & $64.19 \pm 9.40 \mathrm{a}$ & $149.26 \pm 10.83 b$ & $359.82 \pm 13.97 \mathrm{~d}$ & $255.81 \pm 46.54 \mathrm{c}$ & $62.30 \pm 11.90 \mathrm{a}$ \\
\hline trans- $\beta$-Methyl- $\gamma$-octalactone & $18.85 \pm 0.10 \mathrm{a}$ & $13.25 \pm 0.46$ a & $59.52 \pm 13.50 \mathrm{~b}$ & $8.48 \pm 1.52 \mathrm{a}$ & $33.03 \pm 3.03 b$ & $42.73 \pm 7.42 \mathrm{~b}$ & $98.60 \pm 11.04 \mathrm{c}$ & $8.32 \pm 1.02 \mathrm{a}$ \\
\hline cis- $\beta$-Methyl- $\gamma$-octalactone & $152.96 \pm 0.10 \mathrm{c}$ & $20.70 \pm 1.55 \mathrm{a}$ & $65.73 \pm 16.53 b$ & $17.94 \pm 1.28 \mathrm{a}$ & $326.74 \pm 26.75$ c & $72.81 \pm 7.12 b$ & $78.08 \pm 10.34 b$ & $22.00 \pm 1.84 \mathrm{a}$ \\
\hline
\end{tabular}

All parameters are given with their standard deviation $(n=6)$. Different letters in the same row indicate significant differences between different oak woods atn each macerating moment (Duncan test at $\mathrm{p} \leq 0.05$ ). 
Figure 1. Evolution of volatile oak-related compounds: a) furfural, 5-methyl-furfural, 5-hydroxymethyl-furfural, guaiacol, 4-vinylguaiacol and eugenol; b): cis-isoeugenol, syringol, vanillin, trans- $\beta$-methyl- $\gamma$-octalactone and cis- $\beta$-methyl- $\gamma$-octalactone extracted from the oak wood in Carménère wines macerated with different oak chips for three months: Am: American (Quercus alba); Fr: French and Ro: Romanian (Q. petraea); and Co: Colombian (Q. humboldtii) oak chips. The error bars represent standard deviation values.

\section{Figure 1a.}
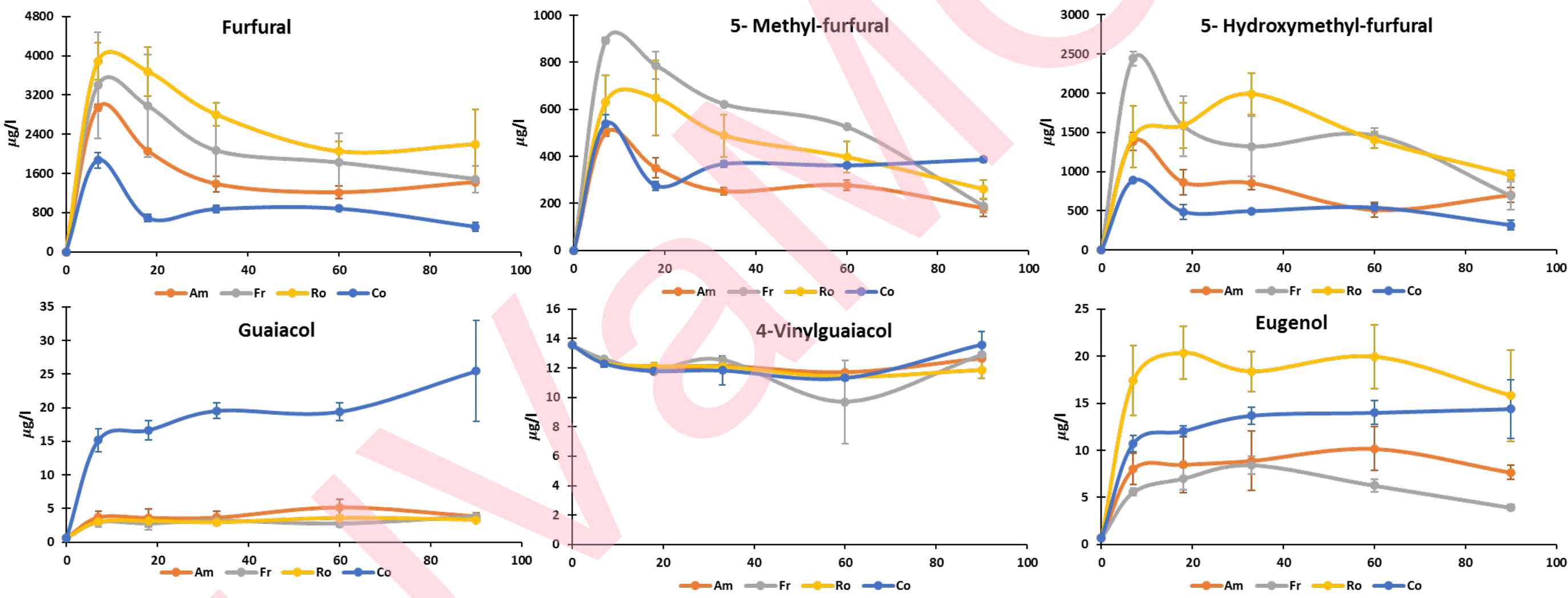
Figure 1b.
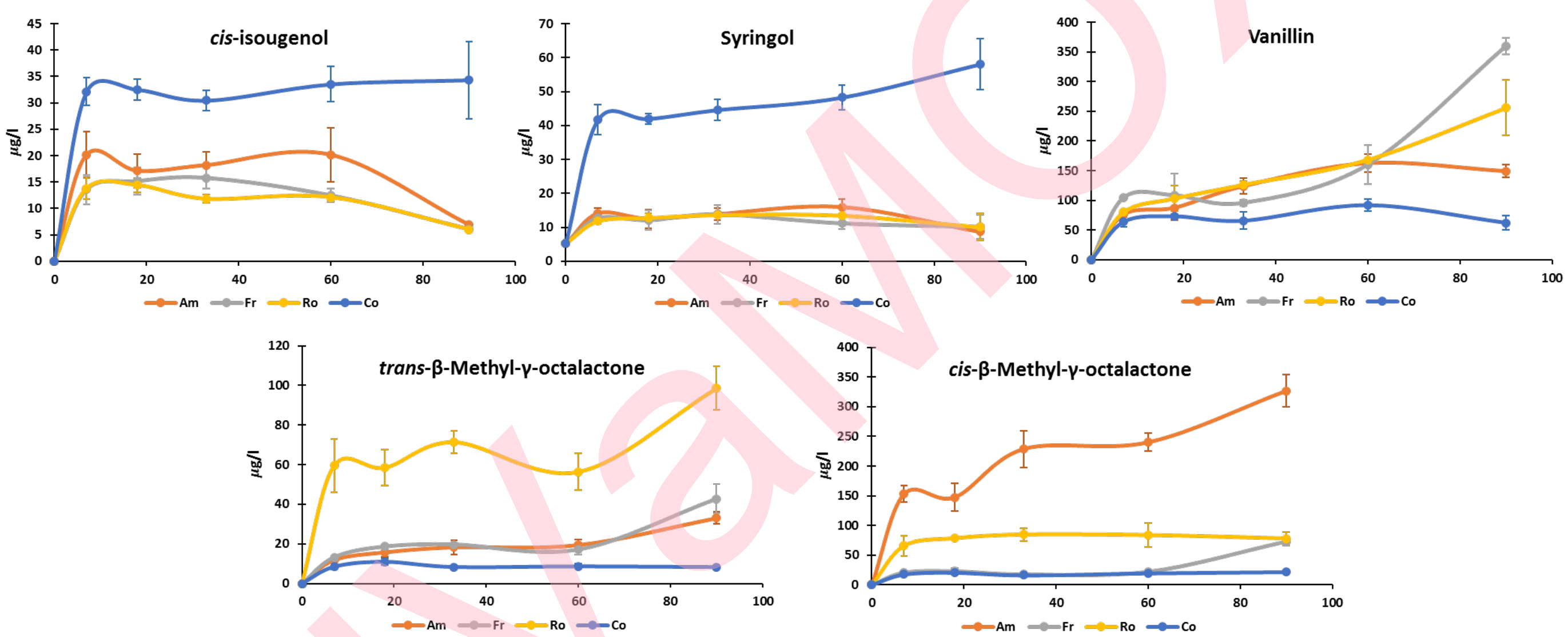
Martínez-Gil, A. M., del Alamo-Sanza, M., Gutiérrez-Gamboa, G., Moreno-Simunovic, Y., \& Nevares, I. (2018). Volatile composition and sensory characteristics of Carménère wines macerating with Colombian (Quercus humboldtii) oak chips compared to wines macerated with American (Q. alba) and European (Q. petraea) oak chips.

Food Chemistry, 266, 90-100. https://doi.org/10.1016/j.foodchem.2018.05.123

Figure 2. Principal component analysis (PCA) performed with volatile compounds: a) in oak chips (Am: American (Quercus alba); Fr: French and Ro: Romanian (Q. petraea); and Co: Colombian) $(\mu \mathrm{g} / \mathrm{g})$ and in Carménère wines $(\mu \mathrm{g} / \mathrm{l})$ macerated with these oak chips; b) for 7 days and c) for 90 days.
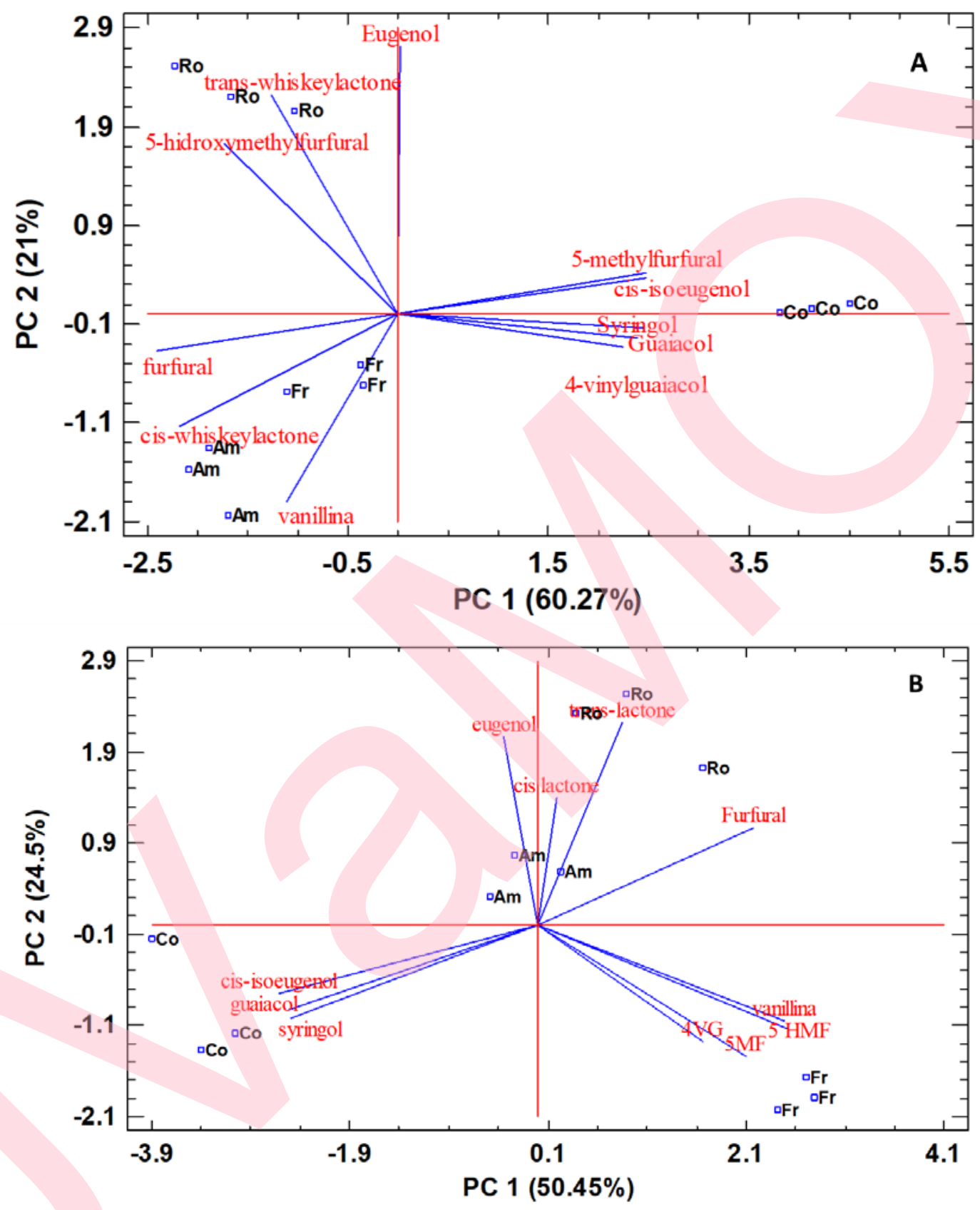
Martínez-Gil, A. M., del Alamo-Sanza, M., Gutiérrez-Gamboa, G., Moreno-Simunovic, Y., \& Nevares, I. (2018). Volatile composition and sensory characteristics of Carménère wines macerating with Colombian (Quercus humboldtii) oak chips compared to wines macerated with American (Q. alba) and European (Q. petraea) oak chips.

Food Chemistry, 266, 90-100. https://doi.org/10.1016/j.foodchem.2018.05.123

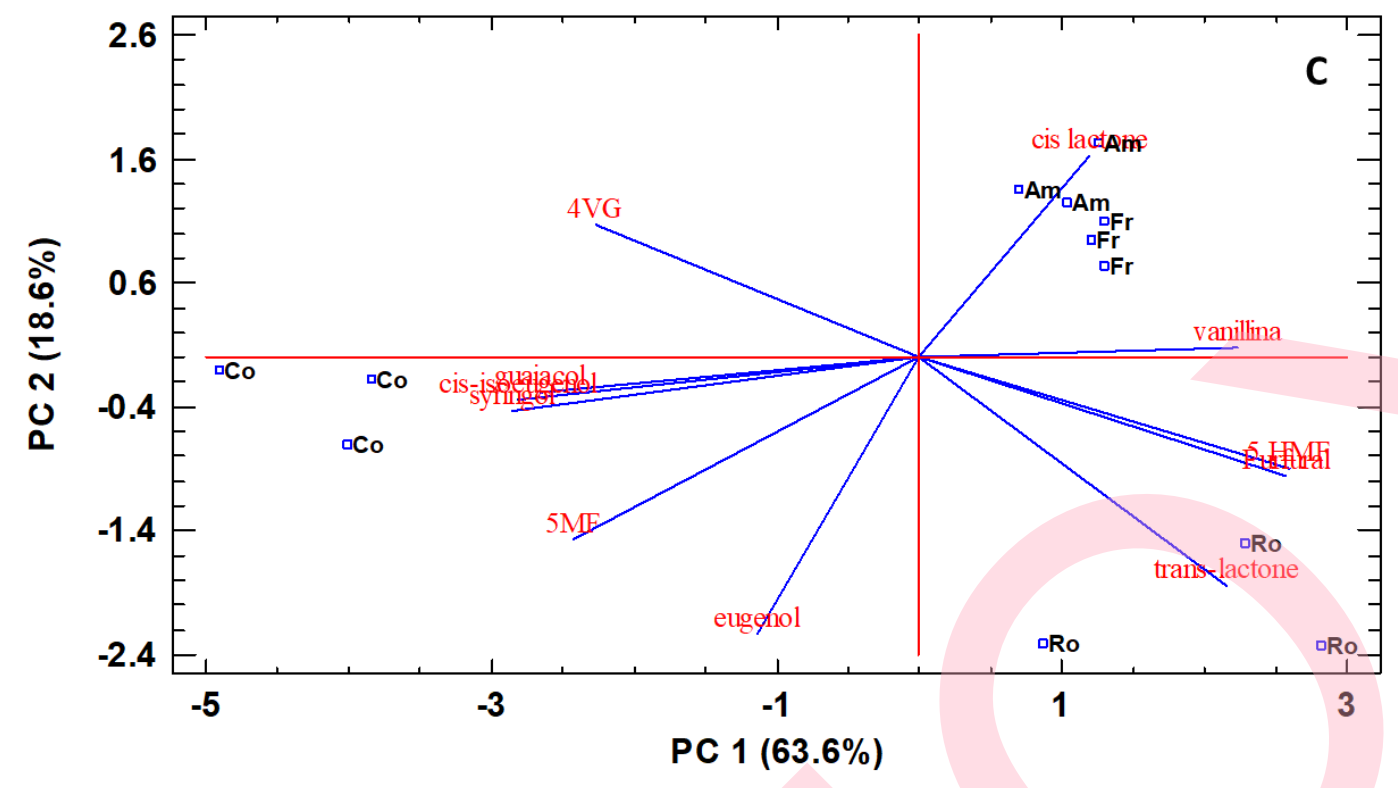


Figure 3. Olfactory and gustative attribute scores of unmacerated wines and those macerated with Quercus alba (American oak), Q. petraea (French and Romanian oaks), and Q. humboldtii (Colombian oak) during 90 days

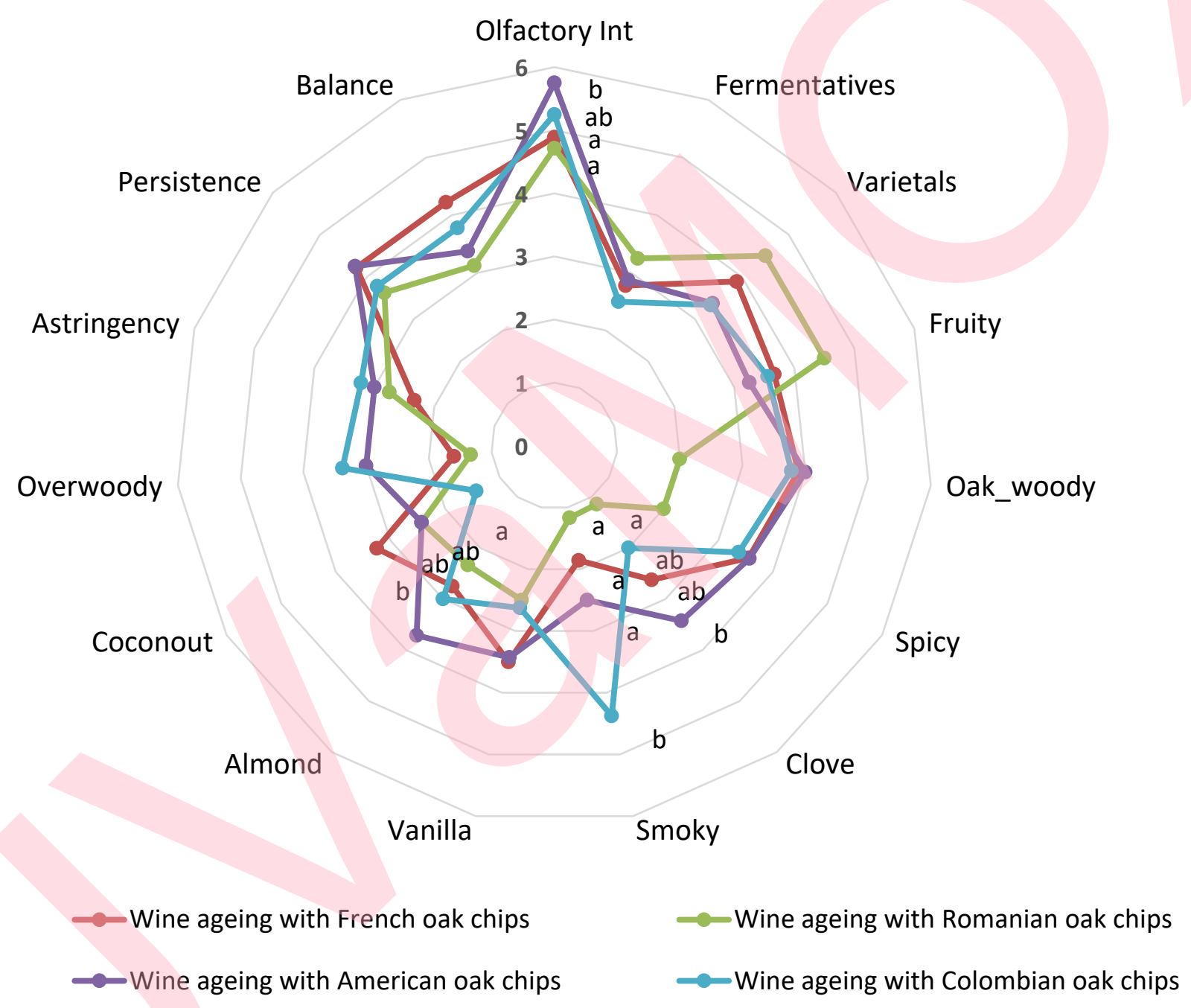

